\title{
Netaji Subhas Chandra Bose: Contributions of a Revolutionary to Indian Social Reforms and Indian Industrial Relations
}

Anuplal Gopalan*

\section{Abstract}

NetajiSubhas Chandra Bose -the fiery Indian revolutionary has been in the news during 2015 and 2016 in connection with the declassification of files about his mysterious disappearance after $18^{\text {th }}$ of August 1945. Of late, maximum research and writings on the leader have been about the mystery and associated theories connected with his disappearance, with the Indian Prime Minister himself taking a keen interest. It is largely History and to some extent Political Science, which as academic disciplines, has incorporated Subhas Chandra Bose as "Topic of Study/Research". Netaji Subhas Chandra Bose had an in-depth knowledge of not only the Indian Society but also Japanese and European Society. He was a very keen observer of Indian Society and with his keen observation and constant interaction with a wide section of the general public during his constant travels, both within India and abroad, he was aware of various social problems particular to India and its magnitude. Netaji Subhas Chandra Bose was also fully aware of the British Colonial interests (the cunning-oppressive Agenda) who did not want the total eradication of social problems,especially that of caste and communal rivalry. Netaji Subhas Chandra Bose had practical experience in

*Assistant Professor of Industrial Relations; St. Joseph's College (Autonomous); Bangalore, India; anuplalgopalan@gmail.com 
Indian Industrial Relations as an Outside Trade Union Leader of various major trade unions and President of the first Indian Trade Union Federation-The All India Trade Union Congress (AITUC). As the President of India's most powerful political party, the Indian National Congress (INC), for two consecutive terms, Netaji's contacts with Indian leaders belonging to different groups/associations including trade unionists, and general public those days was next only to Mahatma Gandhi. All these broadened his horizon and called for constant observation and study of Indian Society on a day to day basis. Netaji also donned the role of conciliator and arbitrator during industrial disputes. Thus his ideas and writings on these areas were a result of practical experience. Netaji Subhas Chandra Bose also tried his level best to ameliorate the social status of Indians and was particularly concerned about the plight of Indian labour and farmers. This Article focuses on the role of NetajiSubhas Chandra Bose in Social Reforms and Industrial Relations and aims at highlighting the fact that Bose can be an interesting 'Topic of Research' even in Sociology, especially Sociology of Indian Social Reforms, Sociology of Indian Industrial Relations and Military Sociology.

Keywords: Netaji Subhas Chandra Bose, Sociology, Industrial Relations, Caste, Social Reforms, Indian National Army (INA), Trade Unions.

\section{Introduction:}

An in-depth study of Social Reforms is integral to Sociology of Indian Society; Similarly, Industrial Relations constitutes the bulk of Industrial Sociology.

Among all the Indian Freedom Fighters, Netaji Subhas Chandra Bose's ranking concerning his contribution to Indian freedom struggle and popularity is next only to Mahatma Gandhi. Historians, military strategists, anti-colonialists and political scientists have had the veteran revolutionary as a subject of serious academic discussions. The towering charisma of Netaji Subhas Chandra Bose as a military leader at the forefront of Indian 
Independence movement (particularly outside India) has dwarfed many of his other contributions-especially as a Social Reformer and Industrial Relations Expert. Netaji Subhas Chandra Bose was a great orator, prolific writer and a doer - one who practised what he preached. Though Netaji has never been a student of Sociology, he was always a keen observer of Indian Society. During his stay in Europe Netaji did establish and develop contacts with Sociologists apart from political leaders, Economists, literati, scientists and people from the cultural world. Netaji Subhas Chandra Bose's ideas, writings, and actionsprovide enough material for serious Sociological research, especially in the field of Sociology of Indian Social Reforms and Sociology of Indian Industrial Relations.

The principal objective of this paper is to highlight the contributions of Netaji Subhas Chandra Bose to Social Reforms in India and Indian Industrial Relations-primarily as an Outside Trade Union Leader and Champion of Labour Welfare and to argue for a serious study of the Revolutionary through the Sociological and Industrial Relations viewpoint.

Apart from the speeches delivered by Netaji Subhas Chandra Bose and official letters and special (Military) orders written by him during his illustrious public life in various capacities, secondary sources have formed a bulk of the data in this paper to give us a better understanding of the issue at hand. Some of the positions Bose held were the President of the Indian National Congress, Mayor of Calcutta, President of TATA Steel Workers Union \& All India Trade Union Congress-AITUC, Head of the Provisional Government of Free India and Supreme Commander of the Indian National Army. Besides the use of Secondary sources, some datain connection with Netaji Subhas Chandra Bose andSocial Reforms has also been gathered via expert interviews of ex -Indian National Army (INA)and Azad Hind Dal Personnel. These interviews will serve as a part of our primary data.

\section{The Role of Netaji Subhas Chandra Bose as a Social Reformer}

Netaji Subhas Chandra Bose's efforts at Social Reforms in a fullfledged manner took off on foreign soil as he took over as Prime Minister of India in Exile and Supreme Commander of the INA. True to his secular and egalitarian outlook with its base in Social 
Justice and Social Equality, Netaji's policy decisions and actions as Head of State in exile, actually initiated a series of Social Reforms which is indeed of much use and interest to students of Sociology. Netaji's constant interaction with Indians of all strata and his wide travel and political activity right from a young age had made him aware of the wide divisions in Indian society. He was concerned with Caste inequality and associated disadvantages resulting in disunity in Indian society and with communal disunity and rivalry among different religious groups in India. During one of his travels (before getting into active politics) he had been at the receiving end of the Indian Caste System. The British Colonialists had used the caste and communal differences and disunity in India to nurture their policy of divide and rule and institutionalised the same even in the Colonial British Indian armed forces.

On the 19th of October 1929, while delivering the Presidential Address at the Punjab Students Conference held at Lahore, Netaji had stated: "By freedom I mean all round freedom... his freedom implies not only emancipation from political bondage but also equal distribution of wealth, the abolition of caste barriers and social inequalities, and destruction of communalism and religious intolerance...so long as social repression and economic inequality weighed heavily on these people, the idea of political independence could not inspire them". During his first term as the President of the Indian National Congress, he decided to set up a National Planning Committee under the aegis of the INC with Pandit Jawaharlal Nehru as its Chairman with the definite aim of transforming an impoverished India into an economically and industrially advanced nation. (Ayer, 1972, p.18).

After taking over direct command of the INA/Azad Hind Fauj, on the 25th of August 1943 and with the establishment of the Provisional Government of Free India on the 21 ${ }^{\text {st }}$ of October 1943 at Singapore, Netaji Subhas Chandra Bose's proclamations and commands resulted in a series of social reformswhich were indeed very revolutionary.The banning of untouchability and all other detrimental caste practices was one of the major social reforms introduced by Netaji Subhas Chandra Bose through the INA. and the Azad Hind Government. The British Colonial rulers had always made it a point to have soldiers predominantly from the so-called' 
martial races' in their colonial army in India. These soldiers, belonging to different communities-Castes, sub-castes, and religions, often dined in separate areas and had separate barracks. This practice indeed was also a convenient means for the calculative British Colonial Masters to avoid 'total unity' of the Indian Soldiers in the Colonial Forces (very much necessary for maintaining command by a much smaller number of British Officers). In short, Indian caste system became another handy tool for their notorious 'Divide and Rule policy'. Nurturing caste practises/caste based restrictions was indeed an agenda of British colonialists to serve their interests in their most prized and biggest colony - India (Hartog, 2001, p.69).

For the first time in the modern military history of India, this caste based practise was given up when Netaji Subhas Chandra Bose ordered and introduced in his Indian National Army, the interdining of Indian soldiers and officers belonging to all castes and all four major religions (Hindu, Muslim, Sikh and Christian). Netaji's first and foremost conditionwhen he took up the reigns of the INA was that the companies of this 'truly Indian' Army should never be grouped into different communities, unlike the way British did. The INA was to be a mixture of various Religions, Races, and Castes with total social equality of all soldierswith no one being inferior or superior on account of their religion, caste or race. They were served food cooked in the common kitchen and shared space in common barracks breaking the age old caste bonds and practices. These were indeed first major successful steps in eradicating casteist feelings and nurturing feelings of 'being Indian' above everything else among the soldiers. Any Indian irrespective of his caste (including non-martial caste) and religious community could enroll in the INA (Hartog, 2001, p.70).

To strengthen the secular feelings and thereby foster National unity, common worship and celebrations of all religious festivals were introducedin the INA. It is interesting to note that the Indian Armed Forces, undoubtedly the most secular Armed Forces in the world, has incorporated these practices initiated by Netaji Subhas Chandra Bose in his INA. The literacy of soldiers and civilians, who were organised under the Azad Hind Dal, was given top priority and with the introduction of Romanized Hindustani, learning 
Hindustani as a common languagefor command words in the Indian National Army became easy. It may be noted that shortly after Independence, the mighty Indian Armed Forces incorporated Hindustani words for military commands/instructions. Netaji Subhas Chandra Bose even commissioned a German-Hindustani Military Dictionary-whose main purpose was to provide Hindustani equivalents for commands in German Army (whose help was initially sought by Netaji for formal training of INA Personnel). Netaji Subhas Chandra Bose in fact successfully experimented with applied linguistics (Hartog, 2001, p.89). Though Hindustani was widely used for military commands and administrative use, all other Indian languages were considered equally important. Also, the Azad Hind Radio Station, which had broadcast stations in Singapore, Bangkok, Rangoon, Tokyo and Saigon beamed to India in some Indian Languages like Bengali, Tamil, Telugu, Kannada, Malayalam, Gujarati, Marathi, Punjabi, Gurkhali and Pushtu apart fromHindustani and English(Ayer,1972, p.52).

Netaji Subhas Chandra Bose had an inherent faith in "Nari Shakti" or 'Women's Power". He favoured Women's empowerment and breaking the social bondage of women-a bane of Indian women for centuries. Netaji was one of the early champions of 'women rights' who strongly believed in the equality of men and women in Civil and Military life and considered the participation of women in the Indian freedom struggle extremely important. Netaji greatly admired Rani Lakshmi Bai of Jhansi, one of the heroines of the First War of Indian Independence. His ideas on 'women empowerment' were not mere lip service. It may also be noted that Netaji was a great devotee of the Mother Goddess-Durga. Netaji Subhas Chandra Bose created a history of sorts on the $22^{\text {nd }}$ of October 1943, by establishing the world's first all Women Regiment within the Indian National Army and christened it "The Rani Jhansi Regiment (as a tribute to the legendary Rani Lakshmi Bai of Jhansi). It was a full-fledged combat regiment with its Indian women soldiers receiving all necessary military training on par with their male counterparts. In his capacity as the Supreme Commander of the INA., Netaji Subhas Chandra Bose personally took great care in the selection of the trainers for the lady recruits of the Rani of Jhansi Regiment. Also, he strictly instructed the veteran trainers to avoid 
inadvertent use of rough and vulgar language while training the ladies, whom Netaji referred to as 'Ranis'(Arya, 2008, p.172).

The traditionally groomed and traditionally dressed Indian woman (in sarees/salwar-kameez) switching over to military attire with guns in their hands was something unthinkable for the times. An Indian lady doctor practicing at Singapore, Dr. Lakshmi Swaminathan was appointed Captain of the first ever modern women's regiment of the World. Dr. Lakshmi was later promoted to the rank of Colonel, thereby becoming the first Woman to hold that rank in modern military history. Col. Lakshmi married her INA Colleague Col. Prem Kumar Sehgal. Lt. Manwati Arya, Lt. Mrs. Thevar and Lt. Mrs. Thomas were other important women officers commissioned in the Indian National Army. It was indeed a great achievement to induct traditional homebound Indian girls and women of South East Asia into the armed forces as combat soldiers with full rigorous military training and also MilitaryNurses with basic military training. Netaji's militant nationalism coupled with his personal charisma and respect cum encouragement for all irrespective of sex, age, race, caste and religion endeared him to the Indian Diaspora in Germany, Japan, Singapore, Malaya, Thailand and Burma (Ayer, 1972, p.52).

Though the British Colonial Armed Forces in India had a large chunk of Indian soldiers with exceptional military qualities, none of them were given higher ranks. 'Racial Supremacy' of the British was very evident in the Colonial Armed Forcesin matters of promotion and other privileges. The Indian National Army enabled the Indian soldiers to move up on the Military hierarchy and occupy high ranks of Major-General. The Indian soldiers were provided opportunities to move up the hierarchy by their meritirrespective of their caste, race or religion. It is only after taking note of high ranks being conferred on Indian soldiers in the Indian National Army, that the British Colonial Army elevated an Indian, K.M.Cariappa, who later rose to the ranks of First Indian General \& Commander-in-Chief, was conferred the Rank of Field Marshall-much later, after his superannuation, to the ranks of a Brigadier (Hartog, 2001, p.70).

Netaji's secular credentials were something which even Mohammed Ali Jinnah, the founder of Pakistan, was convinced of. 
It is interesting to note that a large number of Indian Muslims occupied high ranks in the Azad Hind Government and the Azad Hind Fauj (INA) by their own merit-something unthinkable in the British Indian Army. Unlike the Colonial British, caste, race, sex or religion was never the criteria for occupying high Military and Civilian offices in the Government of India in Exile (Provisional Government of Free India) and the Indian National Army under Netaji's command and leadership. There are also many who strongly feel that the Partition of India on communal lines would never have happened if Netaji Subhas Chandra Bose was present in India and was present for discussions with Jinnah and others. Many Indians from the Minority Communities occupied high positions in the Provisional Government of Free India and the Azad Hind Fauj. Lt. Col. Aziz, Lt. Col. M. Zaman Kiani, Lt. Col. Ehsan Qadir, Lt. Col. Shah Nawaz, Lt.Nazir Ahmed, Lt. Col. Gulzar Sigh, Janab Karim Ghani, Janab D. M. Khan, SardarIshar Singh, Lt. Mrs. Thomasetc. were prominent members of the Minority community Col. Dr. Lakshmi Sehgal nee Swaminathan was the Cabinet Minister in charge of Women's Organisation. It is indeed a matter of Pride that Free India and her mighty armed forces have emulated the noble secular values propagated by Netaji and his colleagues.One of the greatest legacies left behind by Netaji is the highly popular National Salute-“JAI HIND”. Netaji has proclaimed and instructed to the INA Personnel and Indian Civilians in South East Asia that "JAI HIND is our National Salutation, as Indian meets Indian." The marching song of the Indian National Army 'Kadamkadambadhayeja' has been incorporated by free India's Armed Forces. All these have a very strong secular ethos (Ayer, 1972, p.54).

Netaji was always for social ownership and a Socialist state in India where there will be freedom of Individuals in matters of religious worship, equal rights for all, equality and social justice for all citizens. He never believed that economy is the sole cause of social change. He was very clear about the Spiritual grounding of the Indian People. It is interesting to note that though a Leftist by ideology, Netaji Subhas Chandra Bose never negated spirituality and wanted a separate brand of Socialism for India. He was among the very first Leftist-Socialists who found nothing wrong with being spiritualas far as it was not communal/fanatic-spiritualism 
Netaji was conscious of the deep-rooted spirituality of Indian Society. It is very interesting to note that post-1950s a band of Leftists who never negated spirituality (though they were not followers of Netaji Subhas Chandra Bose) emerged in the LatinAmerican/ South American political scene; Dr. Fidel Castro, Daniel Ortega, and Hugo Chavez to name a few.

\section{NetajiSubhas Chandra Bose and Indian Industrial Relations}

During his eventful years in India, before his great escape from house arrest and subsequent departure to Europe and then to South East Asia, Netaji Subhas Chandra Bose was very closely associated with Indian Industrial Relations. His writings and activities in this field provide sufficient material for research in Industrial Sociology/Sociology of Industrial Relations. Among the top Indian Nationalist Leaders, the contributions of Netaji to Industrial Relations in India is next only to Mahatma Gandhi. Sociology of Indian Industrial Relations is blessed with a large quantity of data about various facets of Industrial Relations contributed by Netaji as an outstanding Industrial Relations expert.

Like Mahatma Gandhi, Netaji too had a clear understanding and views on Indian Industrial Relations. Mahatma Gandhi's approach to Industrial Relations is popularly known as the Trusteeship Approach. We can seriously think of a 'Subhashite Approach' to Industrial Relations. His views, writing, and actions about Industrial Relations will be of much interest to students of Industrial Sociology and Industrial Relations.

Netaji's first association with Indian Industrial Relations was in the year 1922 when his political mentor and veteran Indian Nationalist Desh Bandhu Chittaranjan Das got him associated with the Lahore Trade Union Congress. His contributions to Indian Industrial Relations is a direct result of his association with the Indian working class and their trade unions, especially as the Outside Trade Union Leader [President] of Jamshedpur Labour Association, Tinplate Workers Union, and TISCO Worker's Union. He was elected President of India's first Central Trade Union Federation, the All India Trade Union Congress (AITUC) in 1931 there by emerging as the most important Trade Union Leader of not only British India but also in the entire British Colonial Empire. His 
political ideology was Left Wing Nationalism. Thus, it is wellknown that he was sympathetic to the Indian working class and the stance of the political party he founded in 1939(after his resignation from the Indian National Congress)-The Forward Bloc reflected this (Bose, 2002, p.13). Netaji Subhas Chandra Bose was closely associated with trade union movement in Calcutta, Bombay, Nagpur, Jamshedpur and Bokaro. Indian Trade Unionists of the time including Dr.Varaha Giri Venkata Giri, later President of India, he was the first with a trade union background to be elected he greatly influenced President of a Democratic Country, and so were some of the Communist Labour Leaders of the time.

At a time when Indian Industrial Relations is being tilted the employers and foreign MNC giants in the aftermath of Liberalization in 1991, an analysis of Netaji Subhas Chandra Bose's writings and direct action as an Industrial Relations expert is of special significance. As a Nationalist, Netaji was strongly in favour of employing Indians in all Industries operating from Indian soil. His role as an outstanding outside trade union leader was instrumental in the TATA Group preferring Indian workers and higher officials in all its plants. In his letter dated November 12, 1928, addressed to the then Chairman of TATA Steel Mr. N. B. Saklatvala, Netaji said, "One of the most important problems before the Company (TATA Steel) is that it lacks senior officials from India. I have no doubt that if you go ahead with your policy of Indianisation of Tata Steel, you will be able to ingratiate yourself with your Indian employees, your countrymen as well as with public leaders of all shades of opinion". This letter was taken seriously by the TATAs and paved way for the appointment of more Indians in key positions in that Company (Simeon, 1995).

Netaji Subhas Chandra Bose was given the post of the President of TATA Steel Workers Union in the year 1928, as the third President of the union formed in the year 1920. One advantage that Netaji had during his nine-year tenure between 1928-1937 was the Indian Trade Unions Act, 1926 (now known as the Trade Unions Act, 1926) which provides for outside leadership in registered Indian Trade Unions was already in place and his Presidentship in the said union,though not a worker, was perfectly legal. Though the TATA group is now well known as the initiators of various 
progressive labour welfare and social security schemes, it was Netaji's relentless fight including the 1928 strike which he led that ultimately resulted in all these. In fact, there was an attack on Netaji during a meeting in the year 1931 (September 20) which resulted in the disruption of the meeting. Netaji Subhas Chandra Bose's efforts were indeed responsible for the implementation of maternity benefits for women employees of TATA and also the extension of Gratuity and Pensions for all sections of TATA workers. Netaji's fearless and relentless struggles also resulted in a historic Memorandum of Agreement (signed by the Chairman N. B. Saklatvala, General Manager C.A. Alexander, and Netaji Subhas Chandra Bose) resulting in the first ever profit Sharing bonus for Tata Steel workers. It may be noted that profit-sharing bonus for Indian workers became statutory in free India only in the year 1965 with the introduction of The Payment of Bonus Act, 1965 (Simeon,1995, p.70).

It is a fact that initially, the Tatas feared that Netaji Subhas Chandra Bose was a new threat to their capitalist interests. Labour Historians cum Journalists such as Dr. Dilip Simeon and Jane Ajaz Ashraf have brought out evidence to prove the fact that the then TATA big bosses had a role in violently disrupting the meetingof September 20, 1931, addressed by Netaji Subhas Chandra Bose. However, no one could (including the 300 plus hooligans who were involved in attacking Bose's meeting) break his willpower or courage in his fight for worker's rights. The TATAs, who were totally unwilling to negotiate with the strike committee of TATA Steel Workers, had to budge when Netaji Bose took over as the President of the said Union. This was one of the reasons for Netaji Subhas Chandra Bose to strongly advocate the presence of Outside leaders in Trade Unions (Simeon,1995).

Netaji Subhas Chandra Bose strongly advocated the 'Tri-Partite Scheme' of Industrial Relations where in the Government or the State should play a major role in every sphere of Industrial Relations. He considered the State as an indispensable Party in the Industrial Relations Scheme and regarded that the State has the duty of providing employment to citizens or take up the responsibility of maintaining the unemployed citizens. He 
emphasised the need for Social Security and Labour Welfare Programmes(Bose, 2002, p.153).

In the case of any retrenchment of workers, the State must interfere to solve the associated problems satisfactorily and establish Industrial Peace in the Country. Netaji considered labour problems as political problems and highlighted the necessity of various ameliorative programmes for the benefit of Labour. Netaji was fully aware of the vulnerable position of the Indian workers and thus favoured outside leadership in Trade Unions as one of the means of preventing victimization of Trade Union leaders by the employers. He, therefore, strongly opposed the proposal of the Royal Commission of Labour to amend The Indian Trade Unions Act, 1926 which was enacted as a result of a five-year-long struggle by another veteran Nationalist Narayan Malhar Joshi, who is revered as the father of modern Indian Trade Union Movement. It is interesting to note that in Independent India, the first major amendment to the Trade Unions Act, 1926actually resulted in tightening of outside leadership in Indian Trade Unions (Bose, 1997, p.124).

Netaji Subhas Chandra Bose envisaged a Socialist Republic of Indiawherein every citizen should have the right to work and the right to a living wage (highest wage) and not merely a minimum wage whatever be the occupation. He respected the dignity of labour. It may be noted that Netaji had strongly opposed the recommendations of the Royal Commission of Labour for a minimum wage. He was among the first leaders to strongly advocate equality of wages for both men and women in all type of work. On the $4^{\text {th }}$ of July 1931, in his famous speech at the Calcutta Session of the All India Trade Union Congress (AITUC) Netaji proclaimed "I have no doubt in my mind that salvation of India, as of the world, depends on Socialism.....but India should be able to evolve her own environment.......India should, therefore, evolve her own form of Socialism". During his Presidential Address to the third Indian Political Conference in London on the $10^{\text {th }}$ of June 1933, clearly spelling out his vision for the future (of independent India), Netaji Subhas Chandra Bose proudly proclaimed "Free India will not be a land of capitalists, landlords, and Castes". He was also dead against separate electorates (on Communal lines). He 
was optimistic that once the New Free Regime in India is established sufficient attention could be given for the eradication of social problems. He wrote in his August 1942 Article, "India will be able to concentrate her whole attention on the solution of social problems. The most important social problem is that of poverty and unemployment" (Bose,2002, p.149).

Netaji considered literacy of workers as very important. He often warned the peasants and workers to keep away from communal feuds. He considered secular and scientific education as the means to remedy fanaticism and to initiate an economic consciousness. In "Vision of a Free India" (1928), he stated, "There is much in common between a Hindu peasant and a Muslim peasant than between a Muslim peasant and a Muslim Zamindar" (Ayer, 1972, p.33).

Netaji wrote extensively on Indian trade union movement. He advocated the organization of peasants and workers on a Socialist Programme. He was against the policy of the most prominent political party in British India - the Indian National Congress (INC) -which tried to accommodate various capitalistgroups, as it is often detrimental to the working class interest. He was very optimistic about the inner strengths of Indian Trade Unions and advocated the use of trade union power against the British-imperialistic rule in India. According to Netaji, the organised forces of Labour (including peasants) must strive for promoting the cause of India's political emancipation. He warned that if trade unions were to become a loose federation, it would be suicidal to the Indian working class. He considered strikes as an effective weapon in the hands of the exploited working class, to strongly express their grievance and gain their legitimate rights when all other methods fail. In this case, his ideas of strike matched with the ideas of Mahatma Gandhi. Netaji has the credit of leading some major strikes in India for genuine reasons, to great success (Ayer, 1972, p.63).

NetajiSubhas Chandra Bose was very clear that in Free India, it would be the responsibility of the Nationalist Government to look after the welfare of the labourers providing them with a living wage, sickness insurance, and accident related compensation. He wanted various institutions for labour welfare in India. Netaji was 
greatly impressed by the German and other European Labour Welfare Bodies. He gave a detailed account of all these in his article "Free India and Her Problems" published in August 1942 (Bose,2002, p.154).

It is important for students of Industrial Sociology and Industrial Relations to note that many of the suggestions and ideas of Netaji regarding socialist state, literacy of workers, secularism, worker's rights, national integration, labour welfare, etc., finds a place in the objectives of the leading Central Trade Union Federations. All India Trade Union Congress [AITUC], Indian National Trade Union Congress [INTUC] and Centre of Indian Trade Unions [CITU]. These also find a prominent place in the Constitution of India and the recommendations given by the First National Commission of Labour. Netaji's commitment to establish Socialism and develop an exploitation free world order particularly for the working class was 'seriously' taken note of by the British-Indian Intelligence. The Head of the Political Wing of the Bengal Presidency Administration, Mr. A. B. Moberly, in a secret report to his political masters of the British Colonial Government, informed that the Trade Union activities of Subhas Chandra Bose were detrimental to the interest of road transport and the supply of petrol as well. And so "He (Subhas Chandra Bose) should be removed from this form of activities"(Basu, 2009, p.284).

One of his greatest contributions to Industrial Relations was his ability to instill a sense of patriotism and a sense of responsibility to the motherland among the workers with whom he was associated. He was of the strong view that Indian Trade Unions should take an anti-imperialist stand. Left wing Trade Union Federations of India like The All India Trade Union Congress (AITUC), Centre of Indian Trade Unions (CITU), Trade Union Co-ordination Centre (TUCC) \&Hind Mazdoor Sabha (HMS) have incorporated Netaji's ideas of Socialism and anti-imperialism in their Constitution.

\section{Conclusion:}

This paper has been written primarily to highlight the lesser discussed ideas and contributions of the Nationalist Revolutionary Netaji Subhas Chandra Bose. Many of his ideas and efforts in 
connection with Social Reforms and Industrial Relations stand the test of time. Many of his actions as Head of State \& Supreme Commander of INA, has trickled down to institutions Free India.

Mahatma Gandhi and Netaji Subhas Chandra Bose were two Indian Nationalists who were also concerned with social reforms and Labour Rights. Mahatma Gandhi had clearly stated that an entrepreneur has no right to be in business if he cannot pay his workers at least minimum wages. Netaji's views regarding wages were a step further. He was for the payment of highest wagesLiving Wages to labour. He had argued for the same a decade before India's Independence and the establishment of the Republic. He was also for workers' participation in management. It is very interesting to note that the makers of the Constitution of The Republic of India gave importance to the same. Living wages for workers and Participation of workers in management of industries were incorporated under Part IV-Directive Principles of State Policy, Article 43 and Article 43-A respectively. Many Indian Public Sector Industries and few Private Sector Industries have indeed incorporated the Workers Participation in Industries through Joint Councils, Joint Management Councils, Worker-Directors, etc.

Though, unfortunately, the INA personnel were not inductedinto Free India's Armed Forces, the high secular credentials established by Netaji Subhas Chandra Bose in INA has been infused into the three wings of Indian Armed Forces, giving it the honour of being the world's most secular Defence Forces.Netaji laid the foundation for incorporation of Ladies into the armed forces. Free India's armed forces have also extended the tradition. Netaji was a leader with Left leaning ideology and founder of a Leftist Political Party The Forward Bloc, who fully understood the spiritual nature of Indian Society, and thus never negated spirituality. Very interestingly, The Communist Party of India and The Communist Party of India (Marxist), with their strong grounding in atheism, of late seems to agree with Bose on this count and have taken a relaxed stand with regard to its members(including MLAs and MPs) who would like to profess their faith. The Communist Parties have also accepted that they made a mistake in wrongly accusing Bose for seeking German and Italian help in ousting the British. His arguments for outside leadership to some extent in Trade Unions, 
anti-imperialistic stand, etc. are very relevant to this day. He had insisted on workers/Trade Unions' role in National Integration and the same finds mention in the report of the First National Commission of Labour.

No doubt, students of Sociology in India, especially Sociology of Social Reforms, Sociology of Industrial Relations and even Military Sociology will find a treasure of sorts for Sociological research in the writings of Netaji and various writings on Netaji. Academicians in the discipline of Sociology and Industrial Relations can seriously think of introducing 'efforts of Netaji Subhas Chandra Bose as a Social Reformer and pro-labour Industrial Relations Crusader' and include his published speeches and other secondary sources as Study material/reference material in their syllabi. From the recently declassified (and yet to be declassified) Netaji Files, apart from the 'mystery' surrounding his disappearance and associated conspiracy, much can be gathered about his powerful role in social reforms and Industrial Relations. A serious academic interest and study of Netaji Subhas Chandra Bose's contributions to various academic fields including Sociology and Industrial Relations, itself will no doubt be a fitting tribute to the self-sacrificing, selfless revolutionary nationalist reformer.

\section{References}

Ali, S. (2012). Captain Lakshmi: Memoirs and tributes. Bangalore, Karnataka: DYFI Karnataka State Committee \& Chintana Pustaka.

Aryya-, M. (2007). Patriot, the unique Indian leader NetajiSubhas Chandra Bose: A new personalised biography. New Delhi: Lotus Press.

Ayer, S. A. (1997).Story of the I.N.A. New Delhi: National Book Trust.

Ayer, S. A., \&Reddi, B. G. (1962). Selected Speeches of Subhas Chandra Bose. New Delhi: Publications Division, Ministry of Information and Broadcasting, Govt. of India.

Basu, K. (2010). Netaji: Rediscovered. Bloomington, IN: Author House. 
Bhardwaj, R. C. (1994). Netaji and the INA: A commemorative volume brought out to mark the golden jubilee of the Indian National Army (Azad Hind Fauj). New Delhi: Lok Sabha Secretariat.

Bose, M. (1982). The lost hero: A biography of Subhas Bose. London: Quartet Books.

Bose, S. (2014). His Majesty's Opponent. Gurgaon: Penguin Books.

Bose, S. C. (1992). Selected speeches of Subhas Chandra Bose. New Delhi: Publications Division, Ministry of Information and Broadcasting, Govt. of India.

Bose, S. C. (1997). The essential writings of NetajiSubhas Chandra Bose (S. K. Bose \& S. Bose, Eds.). Delhi: Oxford University Press.

Bose, S. C. (1997). The Indian struggle. Delhi: Oxford University Press.

Bose, S. C. (2002). Azad Hind: Writings and speeches, 1941-1943 (S. K. Bose \& S. Bose, Eds.). Ranikhet: Permanent Black.

Hartog, R. (2001). The sign of the Tiger: Subhas Chandra Bose and his Indian Legion in Germany, 1941-45. New Delhi: Rupa\&Co.

Mukherjee, R. (2014). Nehru \& Bose: Parallel lives. Viking-Penguin Books India.

Toye, H. (1962). Subhash Chandra Bose (the springing tiger); a study of a revolution. Bombay: Jaico Pub. House. 